Published by LPMP Imperium

Journal homepage: https:/ / ejournal.imperiuminstitute.org/ index.php/ AKURASI

\title{
EVALUASI FAKTOR EKONOMI MAKRO DALAM MEMPENGARUHI HARGA SAHAM
}

\author{
Slamet Ardi Restiawan, Rinda Asytuti* \\ Ekonomi Syariah, Fakultas Ekonomi Dan Bisnis Islam, IAIN Pekalongan
}

\begin{abstract}
This study was used to determine the effect of macro economy on stock price of PT Telkom's. The condition of macro economic includes SBI, rupiah exchange rate, inflation, and also money supply. This type of research is quantitative using secondary data. The data taken is monthly closing of each variable, the sample used is saturated as much as 48 months. The data analysis method used is multiple linear regression analysis which previously met the classic assumption test requirements and also the hypothesis test. From the results of the analysis, it is known that SBI, rupiah exchange rate, inflation, money supply affect the stock price. Implications and suggestions are explained in the article
\end{abstract}

\begin{abstract}
Abstrak
Penelitian ini digunakan untuk mengetahui pengaruh kondisi makro ekonomi terhadap harga saham PT Telkom. Kondisi makro ekonomi ini meliputi SBI, nilai tukar rupiah,inflasi, dan juga uang beredar. Jenis penelitian ini adalah penelitian kuantitatif dengan menggunakan data sekunder. Data yang diambil adalah closing pricebulanan dari masing-masing variabel, sampel yang digunakan sampel jenuh sebanyak 48 bulan. Metode analisis data yang digunakan adalah analisis regresi linier berganda yang sebelumnya telah memenuhi syarat uji asumsi klasik dan juga telah dilakukan uji hopotesis Dari hasil analisis diketahui bahwa SBI, nilai tukar rupiah, inflasi, uang beredar berpengaruh terhadap harga saham. Implikasi dan saran dijelaskan pada artikel.
\end{abstract}

Keywords: stock price, macro economy

Received: 12 Feb 2020

Revised: 07 Apr 2020

Accepted: 25 Apr 2020

Online: 30 Apr 2020

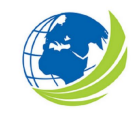

Akurasi: Jurnal Riset Akuntansi dan Keuangan, Vol 2, No.1, April 2020, pp. 21 - 28

eISSN: 2685-2888

$\triangle$ Email korespondensi: rindanadirin@gmail.com

Pedoman Sitasi: Slamet Ardi Restiawan \& Rinda Asytuti. (2020). EVALUASI FAKTOR EKONOMI MAKRO DALAM MEMPENGARUHI HARGA SAHAM. AKURASI: Jurnal Riset Akuntansi dan Keuangan, 2(1), 21-28. DOI: https:/ / doi.org/ 10.36407/ akurasi.v1i2.155 


\section{PENDAHULUAN}

Pergerakan harga saham dapat memberikan petunjuk tentang peningkatan dan penurunan aktivitas pasar modal dan pemodal dalam melakukan transaksi jual beli saham. Lebih spesifik lagi, satu aspek yang paling sering menjadi bahan perbincangan adalah masalah penentuan harga saham dalam perdagangan pasar modal (Maryanne,2009). Harga saham adalah harga saham yang ditentukan oleh pelaku pasar modal berupa pertemuan antara permintaan dan penawaran saham. Untuk melakukan analisis dan memilih saham terdapat dua pendekatan dasar yaitu analisis fundamental dan analisis teknikal. Analisis fundamental mencoba memperkirakan harga saham di massa yang akan dating dengan cara (1) faktor fundamental yang mempengaruhi dan (2) menerapkan hubungan variabel dan diperoleh taksiran harga saham (Deitiana 2011).

Menurut Bursa Efek Indonesia, saham syariah merupakan efek berbentuk saham yang tidak bertentangan dengan prinsip syariah di Pasar Modal. Definisi saham dalam konteks saham syariah merujuk kepada definisi saham pada umumnya yang diatur dalam undang-undang maupun peraturan OJK lainnya. Dalam konteks saham syariah, pengelompokan jenis terdiri dari dua yaitu saham yang dinyatakan memenuhi kriteria seleksi saham syariah berdasarkan peraturan OJK Nomor 35/ POJK.04/2017 tentang Kriteria dan Penerbitan Daftar Efek Syariah, kedua adalah saham yang dicatatkan sebagai saham syariah oleh emiten atau perusahan publik syariah berdasarkan peraturan OJK no. 17/ POJK.04/2015. Berinvestasi di saham syariah juga didukung oleh fatwa Dewan Syariah Nasional NO: 40/ DSN-MUI-XTahun 2003 merupkan halal karena sudah terfilter dari ribuan saham yang ada di dunia.Uang beredar terbagi menjadi uang beredar dalam artian sempit (M1) dan luas (M2) bahwa uang beredar (M1) giro mengalami penurunan sepanjang tahun 2017-2018 (Bursa Efek Indonesia, 2018)..

Tujuan investasi untuk mencapai suatu efektivitas dan efisiensi untuk mencapai tujuan yang diharapkan. Begitu pula hal-halnya dalam bidang investasi, dimana investor perlu menentapkan tujuan yang hendak dicapai, meliputi keberlanjutan dalan investasi, adanya profit, terciptanya kemakmusan bagi pemegang saham, dan merupakan salah satu andil untuk pembangunan bangsa (Fahmi, 2016). Investor dalam memutuskan kebijakan investasi sangat memperhatikan revenue yang akan diperoleh di masa depan. Salah satu bentuk pengembalian tersebut adalah return saham dalam bentuk selisih harga (capital gain). Oleh karenanya, perhatian pada masalah harga dan factor-faktor yang mempengaruhinya menjadi isu yang paling di bidang keuangan.

Faktor makro ekonomi merupakan salah satu factor yang banyak diteliti dan paling banyak memiliki kontroversi terkait dengan harga saham, Studi sebelumnya menemukan hasil yang berbeda dalam menentukan determinan harga saham dari sisi makro ekonomi. Triyono (2018) dalam studinya menemukan bahwa hanya nilai tukar USD / IDR yang memiliki dampak signifikan negatif terhadap IHSG, sedangkan variabel makroekonomi lainnya seperti suku bunga dan inflasi tidak memiliki dampak signifikan terhadap IHSG. Studi lain seperti Mulyani dan Akbari (2019) memberikan kesimpulan yang berbeda dimana harga emas, harga minyak dunia dan nilai tukar memiliki pengaruh positif yang signifikan terhadap indeks saham pertambangan, sedangkan inflasi tidak mempengaruhi indeks saham pertambangan secara signifikan. Ramli dan Musa (2019) memberikan kesimpulan dimana nilai tukar dan harga minyak memiliki pengaruh positif yang signifikan secara statistik terhadap kinerja pasar saham Malaysia sementara tingkat bunga dan jumlah uang beredar memiliki pengaruh negatif yang signifikan secara statistik terhadap kinerja pasar saham Malaysia. Namun, inflasi ternyata tidak signifikan dalam menentukan kinerja pasar saham Malaysia. Bao (2017) menggunakan teknik Granger Causality dan model autoregresi Vektor menunjukkan bahwa hanya jumlah uang beredar yang berdampak pada harga saham. Penelitian ini juga menunjukkan bahwa ketika ada kejutan dalam variabel ekonomi makro, pasar saham butuh waktu lama untuk menyesuaikan diri.

Terkait dengan pasar saham syariah, Chotib \& Huda (2019) memberikan hasil yang menunjukkan bahwa nilai tukar, Sertifikat Bank Indonesia Syariah (SBIS), BI rate, dan Penawaran Uang (M2)/ Jumlah 
Uang Beredar (JUB) seluruhnya memiliki efek signifikan terhadap Indeks Saham Syariah Indonesia (ISSI). Di tahun yang sama, Fadila dan Ardini (2019) juga berhasil membuktikan bahwa suku bunga dan nilai tukar berpengaruh positif terhadap return saham syariah.

Studi yang dilakukan di Iran oleh Pirayesh dan Ganjkhanlou (2016) menunjukkan bahwa ada dampak positif dari variabel nilai tukar dan produksi domestik bruto pada indeks harga bursa, dan juga dampak negatif yang signifikan dari tingkat inflasi pada indeks harga pasar saham. Dalam hal ini, nilai tukar, PDB, dan tingkat inflasi masing-masing memiliki dampak tertinggi pada bursa efek Teheran. Studi lain yang dilakukan oleh HarunaIsahaka et al. (2013) menggunakan kausalitas Granger dan model koreksi kesalahan. Studi ini mengungkapkan bahwa ada hubungan jangka panjang yang signifikan antara return saham dan inflasi, jumlah uang beredar dan Investasi Langsung Asing (FDI). Dalam jangka pendek, ada hubungan yang signifikan antara return saham dan variabel ekonomi makro seperti tingkat bunga, inflasi dan jumlah uang beredar. Koefisien model Vector Error Correction (VECM) menunjukkan bahwa dibutuhkan sekitar 20 bulan bagi pasar saham untuk sepenuhnya menyesuaikan diri dengan posisi ekuilibrium jika terjadi guncangan ekonomi makro.

Penelitian ini secara khusus ditujukan untuk mereplikasi penelitian sebelumnya dengan menempatkan variable-variabel makro ekonomi sebagai prediktor harga saham. Pertanyaan yang ingin dijawab dalam studi ini adalah apakah nilai tukar rupiah, inflasi, jumlah uang beredar, dan suku bunga Bank Indonesia berpengaruh terhadap harga saham PT Telkom yang terdaftar di JII 2015-2018. Penelitian ini dapat memberikan kontribusi untuk literatur tentang determinan harga saham dari sisi ekonomi makro, khususnya pasar saham syariah.

\section{KAJIAN PUSTAKA}

Makroekonomi adalah studi ekonomi secara keseluruhan. Faktor ekonomi makro yang perlu diperhatikan di pasar modal adalah inflasi, suku bunga dan nilai tukar rupiah. Huda dan Nasution (2014) mendefinisikan saham syariah merupakan efek atau surat berharga yang memiliki konsep penyertaan modal kepada perusahaan dengan hak bagi hasil usaha yang tidak bertentangan dengan prinsip syariah. Saham syariah dapat diterbitkan oleh emiten yang memiliki kegiatan bisnis dan pengelolaan usahanya tidak tidak melanggar atau sejalan dengan prinsip-prinsip syariah. Hubungan antara makro ekonomi dengan pasar modal telah banyak diteliti dan memberikan berbagai kesimpulan mengenai efek perubahan makro ekonomi pada pasar saham di sebuah negara. Secara khusus, studi ini mengambil lima variabel makro ekonomi meliputi nilai tukar rupiah, inflasi, jumlah uang beredar, dan suku bunga Bank Indonesia. Dukungan empiris atas hubungan ini telah dibuktikan oleh berbagai studi, baik di dalam negeri maupun di luar negeri.

Suku Bunga dan harga saham

Secara teori, tingkat bunga dan harga saham memiliki hubungan yang negatif. Tingkat bunga yangterlalu tinggi akan mempengaruhi nilaisekarang present value aliran kasperusahaan, sehingga kesempatan-kesempatan investasi yang ada tidak akanmenarik lagi. Tingkat bunga yang tinggi jugaakan meningkatkan biaya modal yang akanditanggung perusahaan dan juga akanmenyebabkanreturn yang diisyaratkaninvestor dari suatu investasi akanmeningkat (Kewal, 2012). Dukungan empiris pada hubungan suku bunga dan harga saham antara lain oleh Chotib \& Huda (2019); Fadila dan Ardini (2019) berhasil membuktikan bahwa suku bunga berpengaruh positif terhadap return saham syariah.

Nilai Tukar Rupiah dan harga saham

Sistemnilai tukar ini menghendaki tidak adanya campur tangan pemegang otoritas moneter suatu negara secara formal dalam rangka menstabilkan atau mengatur nilai tukar mata uangnya. Dengan demikian diharapkan perhatian pemegang otoritas moneter semakin terfokus pada tanggung jawab pengendalian moneter dalam negeri, misalnya pengendalian inflasi domestic (Atmadja, 2004). Mata 
uang yang di masukandalam keranjang biasanya ditentukan oleh besarnya peranannya dalam membiayai perdagangan negara tertentu. Sistem kurs tetap, dimana negara menetapkan dan mengumumkansuatu kurs tertentu atas mata uangnya dan menjaga kurs dengan cara membeliatau menjual valas dalam jumlah yang tidak terbatas dalam kurs tersebut. Bagi negara yang sangat rentan terhadap gangguan eksternal, misalnya memilikiketergantungantinggi terhadap sektor luar negeri maupun gangguan internal, seperti sering mengalami gangguan alam. Hubungan antara nllai tukar rupiah terhadap harga saham antara lain didukung oleh Triyono (2018) ; Mulyani dan Akbari (2019); Ramli dan Musa (2019); Chotib \& Huda (2019).

Inflasi dan harga saham

Inflasi adalah suatu kondisi yang menunjukkan semakin melemahnya daya beli yang disertai semakin merosotnya nilai rill mata uang suatu negara. Inflasi pada umumnya terjadi pada negara yang mana komponen inport yang tinggi untuk menunjang industri dalam negeri, sifat konsumtif dari masyarakat dan tingkat kestabilan politik yang masih senstif terhadap rumor. Inflasi yang tinggi berdampak pada berbagai sendi kehidupan antar lain pengangguran, daya beli turun, daya saing industri melemah pelarian modal dan menaburkan korupsi, dan lainnya. Sumber inflasi (Muis saludin, 2008). Sebagian besar studi menganggap bahwa tingkat inflasi sangat mempengaruhi volatilitas pasar saham dan dampaknya terhadap perekonomian. Udoka, Mboto, dan Anyingang (2013) menyatakan bahwa perusahaan dengan aliran pendapatan yang stabil mengalami penurunan harga saham ketika tingkat inflasi melebihi dari yang diharapkan. Akibatnya, pemegang saham perusahaan tersebut akan menderita pengembalian investasi negatif. Sucuahi et al. (2016) menyatakan bahwa meskipun inflasi dapat secara positif mempengaruhi pertumbuhan harga ternak di antara perusahaan-perusahaan yang terdiversifikasi di Filipina, pengaruh ini tidak dapat dianggap penting. Inflasi memiliki efek negative terhadap harga saham (Pirayesh \& Ganjkhanlou, 2016)

Jumlah Uang Beredar dan harga saham

Definisi yang berbeda tentang jumlah uang yang beredar mencakup juga berbagai jenis deposito yang berlainan. Jumlah uang beredar merupakan suatu stok, yang dirumuskan secara sempit ( M1) meliputi uang kartal dan deposito yang dapat digunakan sebagai alat tukar. Perkembangan pasar uang membuat makin meluasnya pengertian M1.Berbagai teori permintaan uang telah dikembangkan oleh beberapaahli/ ilmuawan. Salah satu teori yang banyak ditelaah dan dibahas oleh sejumlahekonom dunia adalah teori Keynessian. Menurut John Maynard Keynes, permintaanterhadap uang merupakan tindakan rasional. Meningkatnya permintaan uang akanmenaikkan suku bunga. Investasi pada surat berharga (obligasi) pada saat suku bunganaik akan mengakibatkan kerugian capital gain, dari sisi lain apabila suku bungaturun, permintaan surat berharga akan naik. ada tiga macam tujuan seseorangmemegang uang tunai, yaitu motif transaksi, berjaga-jaga dan spekulasi (Nugroho, 2008). Bao (2017) menggunakan teknik Granger Causality dan model autoregresi Vektor menunjukkan bahwa uang beredar yang berdampak pada harga saham.

\section{METODE PENELITIAN}

Desain Penelitian

Fungsi dari desain penelitian adalah untuk memastikan bahwa bukti yang diperoleh memungkinkan peneliti untuk secara efektif menjawab masalah penelitian. Dalam penelitian ilmu sosial, memperoleh bukti yang relevan dengan masalah penelitian umumnya memerlukan bukti tertentu yang diperlukan untuk menguji teori, mengevaluasi program, atau secara akurat menggambarkan suatu fenomena (Hendryadi et al., 2019).

Penelitian ini bersifat kuantitatif jadi menerlukan hipotesis. Hipotesis merupakan jawaban sementara terhadap rumusan masalah penelitian, dimana rumuan masalah penelitian telah dinyatakan 
dalam bentuk kalimat pertanyaandikatakan sementara karena jawaban yang diberikan baru berdasarkan pada teori yang relevan, belum didasarkan pada fakta-fakta empiris yang diperoleh melalui pengumpulan data jadi hipotesis merupakan jawaban teoritis terhadap rumusan masalah penelitian, belum jawaban yang empiris (Sugiyono, 2016). Penelitian ini menganalisis seberapa jauhpengaruh nilai tukar rupiah, inflasi dan jumlah uang beredar terhadap harga saham yang ada di JII tahun 2010-2018. Peneliti menggunakan SPSS.

Variabel Penelitian

Pengukuran variabel dalam penelitian ini didasarkan pada perhitungan dan formula tertentu. Penjelasan mengenai pengukuran tersebut ditampilkan pada Tabel berikut ini:

Tabel 1. Pengukuran variabel

\begin{tabular}{|c|c|c|c|}
\hline No & Variabel & Devinisi variabel & Pengukuran \\
\hline 1. & $\begin{array}{l}\text { Suku bunga } \\
\text { Bank Indonesia }\end{array}$ & $\begin{array}{lll}\text { Perhitungkan } & \text { dari } & \text { pokok } \\
\text { pinjaman } & \text { yang } & \text { harus } \\
\text { dibayarkan } & \text { sebagai } & \text { imbal } \\
\text { jasa } & & \end{array}$ & $\begin{array}{l}\text { Suku bunga nominal(i) = suku } \quad \text { bunga } \\
\text { rill(r)+inflasi diperkirakan(PE) }+ \text { suku bunga } \\
\text { rill(r). inflasi diperkirakan(PE) }\end{array}$ \\
\hline 2. & $\begin{array}{l}\text { Nilai tukar } \\
\text { rupiah }\end{array}$ & $\begin{array}{l}\text { Nilai tukar mata uang negara } \\
\text { kita dengan negara lain }\end{array}$ & Satu dolar AS dibagi Nilai tukar rupiah \\
\hline 3. & Inflasi & $\begin{array}{l}\text { Melemahnya nilai uang dan } \\
\text { daya beli semakin menurun }\end{array}$ & IHK terbaru- IKH lama/ IHK terbaru x 1000\% \\
\hline 4. & $\begin{array}{l}\text { Jumlah uang } \\
\text { beredar }\end{array}$ & $\begin{array}{l}\text { Merupakan uang yang } \\
\text { digunakan oleh masyarakat } \\
\text { dan uang bentuk valas dan } \\
\text { juga simpanan berjangka. }\end{array}$ & Time deposit + uang kartal + demand deposit \\
\hline 5. & $\begin{array}{l}\text { Harga Saham } \\
\text { yang ada di JII } \\
2015-2018\end{array}$ & $\begin{array}{l}\text { Pertemuan permintaan dan } \\
\text { penawaran akan harga } \\
\text { saham }\end{array}$ & $\begin{array}{l}\text { Harga saham = pertemuan antara permintan dan } \\
\text { penawaran saham }\end{array}$ \\
\hline
\end{tabular}

Sumber: diolah

Teknik analisis

Teknik analisis yang digunakan adalah regresi linier berganda dengan bantuan program SPSS. Regresi merupakan teknik untuk menjelaskan variasi harga saham berdasarkan perubahan yang terjadi pada suku bungan BI, nilai tukar, inflasi dan jumlah uang beredar.

\section{HASIL DAN PEMBAHASAN}

Analisis regresi dilakukan setelah melalui uji asumsi klasik diatas. Analisis regresibeganda digunakan untuk mengetahui dan menganalisis variabel dapat dilihat pada tabel berikut.

Tabel 2. Hasil regresi

\begin{tabular}{lrrrr}
\hline Variabel & Koefisien & Std. er & t-value & sig \\
SBI & -199.125 & 66.544 & -2.992 & .005 \\
NILAI TUKAR RUPIAH & -.385 & .124 & -3.095 & .003 \\
INFLASI & -107.043 & 45.792 & -2.338 & .024 \\
UANG BEREDAR & .000 & .000 & 2.076 & .044 \\
Adj. R Square & 0.784 & & & \\
F-statistik & 43.738 & & & \\
\hline
\end{tabular}

Sumber: Data lapangan, diolah 
Uji Koefisien Determinasi ( $\left.\mathrm{R}^{2}\right)$

Koefisien Determinasi $\left(\mathrm{R}^{2}\right)$ pada intinya setiap tambahan satu variabel maka $\mathrm{R}^{2}$ meningkat tidak perduli apakah variabel tersebut berpengaruh signifikan terhadap variabel dependen atau tidak. Dari hasil pengujian tersebut dapat diketahui nilai Ajusted R Square sebesar 0,784. Hal ini berarti 78,4\% harga saham JII dipengaruhi empat variabel dependent (SBI, nilai tukar rupiah, inflasi, uang beredar). Sedangkan sianya sebesar 21,6\% dapat dijelaskan oleh vriabel lain yang tidak termasuk dalam variabel penelitian ini.

Uji kecocokan model (Uji F)

Berdasarkan hasil yang ditampilkan pada Tabel 2 diketahu bahwa signifikan sebesar 0,000< probabilitas 0,05 dan Fhitung 43,738 > Ftabel 2,58 maka keputusan uji F dapat disimpulkan bahwa model regresi yang menempatkan SBI, nilai tukar rupaih, inflai, dan uang beredar sebagai predictor harga saham sudah memiliki kecocokan yang baik sehingga dapat diinterpretasikan lebih lanjut.

Hipotesis dan pembahasan

Dapat disusun persamaan regresi linear sebagai berikut:

Harga Saham JII $=8194.303+(-199.125)+(-0.385)+(-107.043)+0,000+e$

Nilai koefisien konstanta sebesar 8194.303hal ini berarti SBI, nilai tukar rupiah, inflai dan uang beredar maka dalam pasar modal harga saham JII akan bernilai8194.303. b. Nilai koefisien regresi SBI sebesar -199,125 berarti kenaikan satu satuan SBI dengan asumsi variabel independen tetap. Nilai koefisien regresi pada variabel SBI bertanda negatif, maka harga saham JII mengalami penurunan sebesar -199,125. c. Nilai koefisien regresi nilai tukar rupiah sebesar -385 ini berarti setiap kenaikan satu satuan nilai tukar rupiah dengan asumsi variabel independen lainnya tetep. Nilai koefisien regresi pada veriabel nilai tukar rupiah bertanda negatif, maka harga saham JII mengalami penurunan sebesar 385. d. Nilai koefisien regresi inflasi sebesar -107,043 ini berarti setiap kenaikan satu satuan inflasi dengan asumsi variabel independen lainnya tetep. Nilai koefisien regresi pada variabel inflasi bertanda negatif, maka harga saham JII mengalami penurunan sebesar -107,04. e. Nilai koefisien regresi uang beredar 0,000 ini berarti setiap kenaikan satu satuan uang beredar dengan asumsi variabel independen lainnya tetep. Nilai koefisien regresi pada variabel uang beredar bertanda positif, maka harga saham JII mengalami kenaikan sebesar 0,000.

Hasil uji t yang dapat dilihat sebagai berikut: pertama, nilai tukar rupiah berpengaruh terhadap Harga Saham JII yang ditunjukkan dengan besarnya $t_{\text {hitung }}$ lebih besar dari tabel yaitu $(3,095)>2,01669$ dengan nilai Sig $0.003<0,005$ maka disimpulkan bahwa Ha diterimadan $\mathbf{H 0 1}$ ditolak. c. Hasil perhitungan secara parsial variabel inflasi berpengaruh terhadap Harga Saham JII yang ditunjukkan dengan besarnya $t_{\text {hitung }}$ lebih besar dari tabel yaitu $(2,338)>2,01669$ dengan nilai Sig $0.024>0,005$ maka disimpulkan bahwa Ha diterimadan H01 ditolak. d. Hasil perhitungan secara parsial variabel uang beredar berpengaruh terhadap Harga Saham JII yang ditunjukkan dengan besarnya thitung lebih besar dari tabel yaitu 2,076 > 2,01669 dengan nilai Sig $0.0044>0,005$ maka disimpulkan bahwa Ha diterimadan $\mathbf{H 0 1}$ ditolak.

SBI berpengaruh terhadap harga saham PT Telkom yang terdaftar di JII menunjukkan bila SBI meningkat maka para penanam saham akan menambah pembelian saham mereka di pasar modal. Penelitian Yuni Rahmawati (2019) mengatakan bahwa perubahan suku bunga akan mempengaruhi harga saham secara terbalik, ceteris paribus.Artinya jika suku bunga meningkat, maka harga saham akan turun dan sebaliknya. Harga saham yang turunini akan menyebabkan suku bunganaik. Hal ini disebabkan karenadalam menghadapi kenaikan suku bunga, para pemegang saham akan menahan sahamnya sampai tingkat suku bunga kembali pada tingkat yang dianggap normal. Hal ini berarti suku bunga jangka panjang menurun maka pemegangsaham cenderung membeli saham karena lebih menguntugkan. Kenaikan sukubunga akan sangat berpengaruh bagi pelaku pasar modal. Ini menarik 
minat investor yang sebelumnya berinvestasi di bank untuk memindahkan dananyadari saham ke dalam saham dan berorientasi profit yang besar hal ini mempengaruhi naiknya harga saham PT Telkom. Ada pula penelitian yang sejalan adalah penelitian Ardelia Rezeki Harsono (2018) mengatakan bahwa suku bunga memiliki hubungan negatif terhadap IHSG, yaitu apabila suku bunga meningkat maka akan mengakibatkan penurunan IHSG di Bursa Efek Indonesia

Nilai tukar rupiah terhadap Harga Saham JII menunjukkan ada ada pengaruh terhadap harga saham PT Telkom yang terdaftar di JII 2015-2018. Harga saham menigkat maka nilai tukar akan meningkat pula. Saham PT Telkom naik karena banyak penjual dan pembeli yan saling tawar meawar karena ini saling berpengaruh satu sama lain dan menambah profit para investor dari saham PT Telkom. Hal ini berarti jika semakin rendah nilai tukar rupiah menjadikan laba yang dapat dihasilkan dari seluruh aset yang beroperasi menjadi besar terkhusus perusahaan dalam negeri. Penelitian yang menguatkan penelitian Sucuahi et al. (2016) yang menyatakan bahwa meskipun inflasi dapat secara positif mempengaruhi pertumbuhan harga ternak di antara perusahaan-perusahaan yang terdiversifikasi di Filipina, pengaruh ini tidak dapat dianggap penting. Inflasi memiliki efek negative terhadap harga saham (Pirayesh \& Ganjkhanlou, 2016).

\section{KESIMPULAN}

Penelitian ini ditujukan untuk mengetahui pengaruh nilai tukar rupiah, inflasi, jumlah uang beredar, dan suku bunga Bank Indonesia terhadap harga saham PT Telkom yang terdaftar di JII 2015-2018. Berdasarkan hasil analisis diketahui bahwa secara statistic seluruh hipotesis terdukung. Nilai tukar, inflasi, dan SBI memiliki efek negative dan signifikan terhadap harga saham, sedangkan jumlah uang beredar memiliki efek positif signiifkan terhadap harga saham.

\section{Implikasi}

Proses perdagangan saham dan kinerja pasar modal dalam studi ini dipengaruhi kebijakan makroekonomi. Dengan demikian, pembuat kebijakan harus memasukkan proses perdagangan saham dan kinerja pasar modal untuk merancang kebijakan yang tepat. Selain itu, literatur ekonomi menunjukkan bahwa harga saham mencerminkan ekspektasi tentang kinerja perusahaan di masa depan, laba perusahaan, dan tingkat kegiatan ekonomi.

\section{Keterbatasan}

Saran bagi peneliti selanjutnya yang akan melakukan penelitian pada topik yang sama dengan penelitian ini, sebaiknya perlu menambahkan faktor lain yang juga memengaruhi harga saham JII, seperti suku bunga bank syariah, PDB, tingkat pajak, pertumbuhan ekonomi, dan Indeks LQ45, Indeks JII sehingga dapat mengembangkan penelitian ini untuk kedepannya. Jumlah sampel juga sebaiknya ditambah pada penelitian selanjutnya supaya menambah pemahaman akan investasi bagi para pembaca dan juga investor.

\section{REFERENSI}

Atmadja, A. S. (2004). Analisa pergerakan nilai tukar rupiah terhadap dolar Amerika Setelah Diterapkannya kebijakan sistem nilai tukar mengambang bebas di Indonesia. Jurnal Akuntansi dan keuangan, 4(1), 69-78

Bank Indosesia. 2015. Perkembangan Ekonomi Dan Keuangan Daerah.(Kantor perwakilan BI Purwokerto.)

Bao, B. G. (2017). The effects of macroeconomics variables on Vietnam Stock market (Doctoral dissertation, International University-HCMC).

Chotib, E., \& Huda, N. (2019). Analisis Pengaruh Variabel Ekonomi Makro terhadap Indeks Saham Syariah Indonesia (ISSI) periode 2016-2019. JEBA (Journal of Economics and Business Aseanomics), $4(1)$. 
Deitiana, T. (2011). Pengaruh rasio keuangan, pertumbuhan penjualan dan dividen terhadap harga saham. Jurnal Bisnis dan Akuntansi, 13(1), 57-66

Dewan Syariah Nasional NO: 40/ DSN-MUI-X tahun 2003.

Fadila, N., \& Ardini, L. (2019). PENGARUH VARIABEL MAKRO EKONOMI DAN FUNDAMENTAL TERHADAP RETURN SAHAM SYARIAH. Jurnal Ilmu dan Riset Akuntansi (JIRA), 8(5).

Hendryadi, H., Tricahyadinata, I., \& Zannati, R. (2019). Metode Penelitian: Pedoman Penelitian Bisnis dan Akademik. Jakarta: LPMP Imperium.

Huda, N \& Nasution, M.E (2014), Investasi Pada Pasar Modal Syariah, cetakan ketiga, Jakarta: Prenada Kencana

Kewal, S. S. (2012). Pengaruh inflasi, suku bunga, kurs, dan pertumbuhan PDB terhadap indeks harga saham gabungan. Jurnal Economia, 8(1), 53-64.

Maryanne, D. M. D. (2009). Pengaruh Nilai Tukar Rupiah, Suku Bunga SBI, Volume Perdagangan Saham, Inflasi dan Beta Saham Terhadap Harga Saham (Studi Empiris pada Perusahaan Sektor Perbankan di Bursa Efek Indonesia Periode 2004-2007) (Doctoral dissertation, program Pascasarjana Universitas Diponegoro).

Mulyani, E., \& Akbari, F. (2019, September). The Effect of Macroeconomics and Global Commodity Prices on Mining Index on Indonesia Stock Exchange for The Period of August 2016-February 2019. In Third Padang International Conference On Economics Education, Economics, Business and Management, Accounting and Entrepreneurship (PICEEBA 2019). Atlantis Press.

Nugroho, H. (2008). Analisis Pengaruh Inflasi, Suku Bunga, Kurs dan Jumlah Uang Beredar terhadap Indeks LQ45 (Studi kasus pada BEI Periode 2002-2007) (Doctoral dissertation, program Pascasarjana Universitas Diponegoro).

Pirayesh, R., \& Ganjkhanlou, G. H. (2016). An Examination of Macroeconomics Variables Impact on Tehran Stock Exchange Index. Journal of Administrative Management, Education and Training, 12(4), 568-581.

Ramli, M. N., \& Musa, N. S. I. (2019). Effect of macroeconomics variables on stock prices in Bursa Malaysia.

Sucuahi, W. T., Alvarez, J. A. E., Gudes, M. A. M., \& Parsacala, R. B. B. (2016). Influence of Inflation Rate to Stock Price Growth among Diversified Companies in the Philippines. International Journal of Accounting Research, 42(3968), 1-8.

Triyono, D. (2017). The effect of foreign stock indexes and Indonesia's macroeconomics variables toward Jakarta Composite Stock Price Index (JCI). Advanced Science Letters, 23(8), 7211-7214.

Udoka, C. O., Mboto, H. W., \& Anyingang, R. A. (2013). THE EFFECT OF INFLATION ON STOCK MARKET PERFORMANCE IN NIGERIA, 1980 -2010. International Journal of Marketing and Technology, 3(8), 16-29.

\title{
PROFIL PENULIS
}

Slamet Ardi Restiawan merupakan mahasiswa di Fakultas Ekonomi Bisnis Islam IAIN Pekalongan angkatan 2015 yang menyelesaikan kuliah S1 selama empat setengah tahun yang berkeinginan menjadi pengusahan yang bekerja tidak terikat oleh perusahaan.

Rinda Asytuti adalah dosen Fakultas Ekonomi Bisnis Islam IAIN Pekalongan. Penulis memiliki ketertarikan pada penelitian ekonomi islam. Email yang dapat dihubungi di: rindanadirin@gmail.com

\author{
Akurasi: Jurnal Riset Akuntansi dan Keuangan, Vol 2, No.1, April 2020, pp. 21 - 28 \\ eISSN: 2685-2888 \\ Journal homepage: https:/ / ejournal.imperiuminstitute.org/index.php/ AKURASI
}

